розвитку особистості кожного учня. Поєднання двох напрямів використання мистецтва в школі- виховання через мистецтво (мистецтво як викладання загальноосвітніх предметів) i виховання у мистецтві (викладання мистецьких дисциплін) - створюють емоційну атмосферу привабливості, шкільного життя учнів і вчителів.

Отже, у професійному становленні фахівця i, зокрема, майбутніх учителів початкової школи суттєвим є формування особистої позиції: установки, ставлення до професійної художньо-педагогічної діяльності, образотворчого мистецтва.

\title{
Література
}

1. Архангельский С. И. Лекции по теории обучения в высшей школе / С. И. Архангельский. - М. : Высшая школа, 1974. - 278 с. 2. Белкин А. С. Ситуация успеха. Как ее создать: [кн. для учителя] / А. С. Белкин. - М. : Просвещение, 1991. 176 с. 3. Бодалев А. А. Психологические условия гуманизации педагогического общения / А. А. Бодалев // Сов. педагогика. - 1990. - № 12. - С. 65-71. 4. Дидактика современной школы: [пособие для учителей] / Б. С. Кобзарь, Г. Ф. Кумарина, Ю. А. Кусый и др.; под ред. В. А. Онищука. - К. : Рад. шк., 1987. - 351 с. 5. Кэррол Э. Изард. Психология эмоций / Кэррол Э. Изард. - Санкт-Петербург, 2000. 6. Лафренье Питер. Эмоциональное развитие детей и подростков/ Лафренье Питер. - СПб. : прайм - ЕВРОЗНАК, 2004. - 256 с. 7. Платонов К. К. Краткий словарь системы психологических понятий / К. К. Платонов. - М. : Высшая школа, 1984. $-412 \mathrm{c}$.

УДК 378

Лілія Сушенцева

\section{ВПЛИВ ГЛОБАЛІЗАЦІЙНИХ ПРОЦЕСІВ У СУСПІЛЬСТВІ НА ЗМІСТ ПІДГОТОВКИ ПРОФЕСІЙНО МОБІЛЬНОГО КВАЛІФІКОВАНОГО РОБІТНИКА}

Сушенцева Л. Л. Вплив глобалізаційних процесів у суспільстві на зміст підготовки професійно мобільного кваліфікованого робітника.

У статті розглянуто актуальні питання впливу глобалізаційних процесів у суспільстві на відбір і структурування змісту підготовки майбутніх професійно мобільних кваліфікованих робітників. Розкрито сутність глобалізації та іiі політичні, економічні, культурні й соціальні аспекти. Обгрунтовано зростання інтересу до проблеми формування професійної мобільності майбутніх кваліфікованих робітників в умовах глобалізаційних змін у суспільстві та появі ринку праці.

Ключові слова: глобалізація, професійна мобільність, ринок праці, зміст професійної підготовки, кваліфіковані робітники.

Сушенцева Л. Л. Влияние процессов глобализации в обществе на содержание подготовки профессионально мобильного квалифицированного рабочего.

В статье рассмотрены актуальные вопросы влияния глобализационных процессов в обществе на отбор и структуризацию содержания подготовки будущих профессионально мобильных квалифицированных рабочих. Раскрыта сущность глобализации и ее политические, экономические, культурные и социальные аспекты. Обоснованно рост интереса к проблеме формирования профессиональной мобильности будущих квалифицированных рабочих в условиях глобализационных изменений в обществе и появления рынка труда.

Ключевые слова: глобализация, профессиональная мобильность, рынок труда, 
содержание профессиональной подготовки, квалифицированные работники.

Sushentseva L. L. The influence of globalization processes in society on the content of training professionally mobile skilled workers.

The article covers topical issues concerning the influence of globalization processes in society on choosing and structuring the content of training future professionally mobile skilled workers. The author highlights the essence of globalization and its political, economic, cultural and social aspects. The author also substantiates the growing interest in forming professional mobility of future skilled workers in the context of globalization changes in society and appearing a labour-market.

Key words: globalization, professional mobility, labour-market, content of professional training, skilled workers.

Упродовж 90-х років XX століття значно зросла інтенсивність міжпрофесійних переміщень фахівців. Зміна професії стає явищем легітимним і сприймається як поведінково нормальна реакція індивіда на нові умови на ринку праці. Соціально нормальною й цінною стає кар'єра, що передбачає мобільність, перекваліфікацію і перенавчання. Сучасні переміщення здебільшого відбуваються між професіями «далекими» за змістом та умовами праці, за рівнем і профілем освіти й підготовки [6]. Однією 3 нових вимог до діяльності й розвитку майбутнього кваліфікованого робітника $\epsilon$ мобільність. Підсилюючими факторами цієї вимоги $є$ динамічність розвитку ринку праці і ринку професій, поява нових професій, посилення залежності кар'єрного зростання від здатності швидко реагувати на вимоги суспільства та ринку праці та ін.

Зміни цивілізаційного значення, що відбуваються в сучасному світі, поєднують у собі високий динамізм і всезагальний характер. На розвиток держави і суспільства впливають дві надзвичайно важливі тенденції: перехід до науково-інформаційних технологій і глобалізація суспільних проблем. На думку В. Кременя, перехід до науково-інформаційних технологій головний акцент ставить на розвитку людини, що $€$ показником «рівня прогресу кожної країни» та розвитку індивідуальності, що «набуває статусу головного важеля подальшого розвитку будь-якої країни», а тенденція глобалізації означає, що «конкурентність, змагальність, суперництво націй, країн, держав набуває глобального, загальнопланетарного характеру й охоплює буквально всі сфери життя»[7, с. 3]. За таких умов, зауважує С. Іванченко, «виникають нові види діяльності, що ставлять людей перед необхідністю мобільно реагувати на зміни, які відбуваються, найбільше в ситуації невизначення та ризику» [3, с. 25]. Поступово і сама людина починає все більше усвідомлювати свою самоцінність й унікальність, свою роль у побудові суспільства. Образ сучасної людини асоціюється 3 образом людини, спроможної «вибудовувати свою життєдіяльність». Тому традиційний зміст професійно-технічної освіти не відповідає сучасним вимогам як роботодавців, так і самих учнів, які здобувають ту чи ту професію у професійно-технічному навчальному закладі. За такого підходу до підготовки майбутніх кваліфікованих робітників виникла суперечність між потребами особистості, суспільством і системою професійно-технічної освіти.

Метою статті є висвітлення проблеми впливу глобалізаційних процесів у суспільстві на зміст підготовки професійно-мобільного кваліфікованого робітника.

У зв'язку з розвитком інформаційних і телекомунікаційних технологій та появою Інтернету в останні десятиліття розпочався процес глобалізації. Багаточисельні дискусії навколо цього поняття свідчать, що під глобалізацією розуміється низка змін, 
що розглядаються як свідчення нового типу економіки - «економіки знань». За визначенням О. Новікова [9], глобалізація - це «процес всесвітньої економічної, політичної й культурної інтеграції, основними характеристиками якого є поширення капіталізму в усьому світі, світовий поділ праці, міграція в масштабах всієї планети грошових, людських і виробничих ресурсів, а також стандартизація економічних і технологічних процесів і зближення культур різних країн».

Глобалізація має політичні, економічні, культурні та соціальні аспекти. 3 політичної позиції глобалізація послаблює роль національних держав; через спрощення міграції людей i вільного переміщення капіталу за кордон також зменшується вплив держави на своїх громадян. Глобальні зміни викликають структурні зрушення в економіці (перетворення галузевої структури господарства, зміна співвідношень правових форм підприємств) та зміни у свідомості людей. Це пов'язано передовсім зі зміною ставлення до необхідності зміни професії, професійного статусу та роду занять, зміни фаху, робочого місця, статусу в організації внаслідок зміни місця проживання, погіршення стану здоров'я тощо [3]. Економічними аспектами глобалізації $\epsilon$ вільна торгівля, вільний рух капіталу, зниження податків на прибуток підприємств, простота переміщення промисловості між різними державами в інтересах зменшення витрат на працю і природні ресурси. Для культурної глобалізації характерне зближення ділової і споживчої культури між різними країнами світу, широке використання англійської мови для міжнародного спілкування, стрімке розширення мережі Інтернету для одержання інформації і спілкування, поширення по всьому світу американських фільмів, телепередач i програмного забезпечення, а також зростання міжнародного туризму. Соціальний аспект глобалізації виявляється у появі можливості вибору країни проживання та покращення матеріального забезпечення громадян завдяки трудовій міграції.

Проте поряд із позитивними аспектами цього явища на думку О. Новікова, глобалізація має і негативні сторони, у першу чергу через те, що вона здійснюється під контролем США й в інтересах США [9]. Зауважимо, що Україні сьогодні відведено пасивну роль постачальника сировини, а не реального лідера нового альтернативного шляху розвитку людства. Такий підхід значно послаблює нашу вітчизняну систему освіти. Водночас у нас накопичений значний арсенал народних традицій, в основі яких лежить духовність, і педагогічний досвід, що надає змогу здійснювати випереджувальний розвиток професійно-технічної освіти.

Ключовими елементами стратегії забезпечення конкурентоздатності європейської економіки й соціальної згоди є освіта, навчання й навчання протягом всього життя. Проте, як зауважує А. Кінах, головною проблемою сучасної освіти в Україні $є$ неадекватність рівня її якості та змісту стратегічної спрямованості розвитку світової цивілізації [5]. Адже зміст професійної освіти всіх рівнів значною мірою впливає на формування й розвиток суспільства. Тому роз'єднаність європейських освітніх систем була визнана перешкодою задля розв'язання завдань формування єдиної Європи, у рамках якої повинне бути забезпечене вільне пересування праці (робочої сили), товарів і капіталу. У цьому зв'язку основними принципами розвитку інтеграційних процесів $є$ : формування узгодженої освітньої політики на вищому політичному рівні, участь у їі формуванні й реалізації всіх зацікавлених сторін, включаючи соціальних партнерів, опора на масив практичних наробок i експерементальних програм і проектів, реалізованих 3 ініціативи Європейської комісії, участь широкої громадськості в обговоренні нових векторів розвитку й шляхів досягнення поставленої мети, поступовий і поступальний характер інноваційних, і в тому числі інтеграційних, процесів. Основні завдання розвитку інтеграційних 
процесів у галузі освіти є похідними тих завдань, які були зафіксовані в Лісабонській резолюції (березень 2000 р.), і містять у собі: офіційне визнання центральної ролі освіти як фактору економічної й соціальної політики й засобу підвищення конкурентоздатності Європи у світовому масштабі, зближення іiі народів і повноцінного розвитку громадян; радикальний перегляд і модернізацію систем освіти; перетворення СС у найбільше що динамічно розвивається економіку, засновану на знаннях, посилення взаємодії між політикою в галузі економіки, зайнятості й розвитку людських ресурсів за рахунок розвитку високоякісної професійної освіти й навчання й підвищення віддачі від інвестицій у людські ресурси. Варто особливо підкреслити, що інтеграційні процеси жодною мірою не припускають уніфікації систем освіти, навпаки, вони припускають збереження культурного багатства і мовної розмаїтості Європи, заснованої на національних традиціях [10]. Розмаїтість i розходження в європейських системах освіти й навчання $є$ їх достоїнством і основою для обміну досвідом і взаємним навчанням. У контексті поставлених завдань професійно-технічна освіта стає центральним механізмом розв'язання економічних і соціальних завдань, у зв'язку з цим визнано необхідним різко збільшити інвестиції в людський капітал і підвищити ефективність систем освіти й навчання, а й відповідно модернізувати зміст професійно-технічної освіти.

На сучасному етапі в розвитку вітчизняної освіти в умовах входження іiі до єдиного Європейського економічного простору спостерігається низка тенденцій: усе більша частина працездатного населення віддає перевагу тій діяльності, що максимально дозволить реалізувати їх здібності, самостійно приймати рішення, розраховувати на подальше професійне зростання, приділити більше уваги сім’ї, самоосвіті, культурному дозвіллю, заняттям спортом тощо; складність подолання психологічного бар'єру, страху при переході із позиції найманого державного робітника до позиції активного суб'єкта на ринку праці (необхідно самому шукати більш високооплачувану роботу, одночасно працювати в кількох місцях, самому приймати рішення тощо); у ринкових умовах людина змушена змінювати не тільки місце роботи, а й професію, що не вкладається у традиційні стереотипи, коли кращим вважався той робітник, який тривалий час працював на одному місці; тобто нині необхідно готувати такого кваліфікованого робітника, який би мав таку базову освіту, яка б забезпечувала легше оволдіння новими професіями в майбутньому (освіта повинна бути конвертованою, а випускник професійно-технічного навчального закладу - професійно мобільним); структурні зміни в економіці, запровадження інформаційних і високих наукоємних технологій поділило працездатне населення на дві категорії: професіоналів високого класу (невеликий прошарок професійної еліти) та достатньо освічених або високоосвічених робітників, які легко можуть переходити від однієї професійної діяльності до іншої, з однієї галузі в іншу залежно від змін в економіці чи за власним бажанням; на перший план виходить рівень розвитку людських ресурсів (знання, уміння, майстерність, творчість, професійна мобільність); потреба в робочій силі стала виражатися не стільки в кількісних, скільки в якісних показниках; значне скорочення фахівців середньої ланки (бригадирів, майстрів, змінних інженерів та ін.) викликало потребу у кваліфікованих робітничих кадрах, здатних до самозайнятості, самостійності у прийнятті рішень, до роботи в малих самоуправляємих командах, що потребує оновлення змісту професійно-технічної освіти, зокрема на основі модульно-компетентнісного підходу.

Нині в усіх цивілізованих країнах, як зауважує Н. Ничкало, здійснюється інтенсивний пошук нових моделей розвитку освіти, нетрадиційних підходів до їх впровадження на основі інформаційних і телекомунікаційних технологій [8, c.19]. 
Основою стабільності соціально-економічного життя країни та подальшого ії розвитку $є$ відтворення і нарощування людського потенціалу, головним чинником якого $\epsilon$ освіта. Від людського капіталу, від духовних, морально-етичних i професійних якостей його залежить майбутнє держави [8]. Як підкреслюється в документах Копенгагенського процесу, його найважливішим аспектом є соціальний, а це означає, що прагнення до збільшення конкурентоздатності повинно супроводжуватися прагненням до поліпшення соціальних параметрів загальноєвропейського простору професійної освіти й усуненню прояву соціальної нерівності як на національному, так і на європейському рівні. У цьому контексті освіта визнається суспільним благом, відповідальність, за яке несуть державні структури. Інакше кажучи, реалізація процесу професійної освіти і навчання повинна регулюватися й регламентуватися на державному рівні.

Згідно з даними Міжнародної Організації Праці, гнучкість і переміщення між професіями - один із найбільш важливих результатів бурхливих технологічних i структурних змін світової економіки. У радянські часи людина приходила на роботу й бачила перед собою чіткий шлях, сходи, якими він може дійти до якоїсь позиції. Нині така ситуація також має місце, але людина тепер дивиться не тільки вперед, а ще й у різні боки, бачить ці «сходи» i в інших місцях. I почасти рухається «зигзагоподібно» [2]. Тож сучасні умови розвитку суспільства зробили зміну професії широко розповсюдженим явищем, яке можна розглядати, на нашу думку, як прагнення до самореалізації або самоствердження в іншому професійному середовищі. При цьому зміни відбуваються у всій структурі особистості людини під впливом зовнішніх чинників.

Виокремлюючи професійну мобільність фахівця як одну 3 головних проблем розвитку економіки країни, Л. Горюнова розмежовує три взаємозалежних сутності професійної мобільності, що визначаються як якість особистості, що забезпечує внутрішній механізм розвитку людини; діяльність людини, детермінована подіями, що змінюють середовище, результатом таких змін $є$ самореалізація людини у професії й житті; процес перетворення людиною самої себе й оточуючого її професійного й життєвого середовища [1].

Зростання інтересу до проблеми формування професійної мобільності майбутніх кваліфікованих робітників зумовлено гуманістичною функцією неперервної освіти, яка надає змогу кожній людині обирати індивідуальну освітню траєкторію, одержувати ту професійну підготовку, яка їй необхідна для кар'єрного і особистісного зростання, самореалізації в тій чи тій професійній діяльності [4].

Проблему зміни виду професійної діяльності досліджували науковці. Зокрема, Н. Хакімова розглядає зміну професії особистістю у зрілому віці як тривале професійне самовизначення. Зміна професії зумовлює не тільки зміну звичного способу життя, але і стосуюються найважливіших аспектів людського життя. Деякі автори вказують на те, що професійна переорієнтація та зміна професійного шляху це соціальна дія, яка має ті або інші психологічні наслідки, яка завжди пов'язана 3 певним психологічним станом особистості. Оптимальною $є$ ситуація, коли особистість у процесі професійної переорієнтації знаходить своє покликання й успішно адаптується до умов обраної професії. Але якщо людина продовжує пошук довго або пошук не дає позитивних результатів, це $є$ чинником, що спричиняє розвиток незадоволеності собою, професією, життям загалом. У цьому випадку йдеться про ціннісно-смислову сфера особистості, так само цінностями і смислами людина керується у процесі вибору оволодіння новою професією. Якщо людина не досить мобільна - зміна професії може супроводжуватися періодом безробіття. Це 
явище, за якого частина економічно активного населення не може застосувати свою робочу силу і залишається в резерві [11].

Проте, на наш погляд, поява різномасштабних і різноспрямованих інтеграційних процесів, що охопили практично всі сфери економічного та соціального життя людини, зумовлює стирання територіальних та соціально-психологічних кордонів життєдіяльності людини. Якщо раніше природним вважався осідлий спосіб життя, то нині все кардинально змінилося. На сучасному етапі однією 3 необхідних якостей людини вважається мобільність, зокрема професійна, яка розглядається як одна із найважливіших якостей кваліфікованого робітника.

У сучасних соціально-економічних умовах, коли в Україні розвиваються ринкові відносини, необхідно, щоб зміст професійно-технічної освіти забезпечував формування у випускників професійно-технічних навчальних закладів готовність і здатність до професійної мобільності. Сучасна людина повинна мати внутрішню гнучкість, різноманітні інтереси, розуміти «цінність самовдосконалення» [3]. Водночас дослідження науковцями (І. Заюков, Е. Лібанова, Г. Ярошенко) проблем розвитку механізму взаємодії ринку праці і професійної освіти України свідчать, що «нині в Україні загострюється проблема взаємодії ринку праці та ринку освітніх послуг, унаслідок невідповідності структури підготовки фахівців і робітників попиту на робочу силу» $[12$, с. 25$]$. Незаперечним $є$ факт, що значна частина випускників професійно-технічних навчальних закладів працює не за здобутою професією, а дехто змушений одзразу ж після закінчення професійно-технічного навчального закладу звертатися до Державної служби зайнятості. Це пов'язано, на думку переважної більшості науковців, з неконкурентоспроможністю робочих місць, в основу якої покладено низьку вартість робочої сили. В економічній літературі $є$ поняття «період напіврозпаду компетентності», тобто період протягом якого знання та вміння випускника професійно-технічного навчального закладу застарівають наполовину i він стає непридатним до професійної діяльності [12]. Особливо це небезпечно, коли у стані безробіття перебувають тривалий час. Це впливає не тільки на професійний, а й життєвий рівень, спричинює втрату кваліфікації, трудових умінь та навичок, і як наслідок - фактичне руйнування особистості. Тому нині особливо гостро постає проблема, проектування змісту професійно-технічної освіти на основі модульнокомпететнісного підходу, щоб «забезпечити динамічно змінюваний ринок праці робітниками певних, соціально затребуваних спеціалізацій, які володіють необхідним рівнем кваліфікацій і професійною компетентністю» [4, с. 44]. Тобто сьогодні на перший план виходять потреби професійної сфери, галузей виробництва та інфраструктури суспільства. Водночас зауважимо, що справа тут не тільки у задоволенні суспільних потреб, але й у соціальній захищеності сучасного випускника професійно-технічного навчального закладу, який повинен бути професійно мобільним i щоб за будь-яких «прискорень» науково-технічного прогресу не залишитися на узбіччі життя. Тому проектування змісту професійно-технічної освіти повинно бути зорієнтоване передовсім на забезпечення умов формування готовності учнів до професійної мобільності, на оволодіння ними нових видів і способів професійної діяльності, нових кваліфікацій i компетенцій, набуття професійної майстерності в обраній галузі трудової діяльності.

У контексті модернізації системи професійно-технічної освіти в Україні підготовка професійно мобільних кваліфікованих робітників, які добре знають свою справу, здатних творчо розв'язувати професійні завдання, $є$ визначальним чинником, що характеризує діяльність професійно-технічного навчального закладу. Професійнотехнічний навчальний заклад розглядаємо як відкрите освітнє середовище, що являє 
собою сукупність багатьох умов та факторів, що сприяють розвитку особистості учня та забезпечують формування професійно мобільного кваліфікованого робітника у взаємодії із соціальним, професійним та інформаційним оточенням. Водночас ми розглядаємо професійно-технічну освіту як процес і як результат професійного становлення та розвитку особистості майбутнього кваліфікованого робітника. При цьому відкрите освітнє середовище може мати як позитивний, так і негативний вплив на становлення особистості учня, iї соціалізацію та професіоналізацію. Виходячи 3 цього, актуалізується завдання створення нових ефективних форм функціонування системи професійно-технічної освіти, здатних підвищити якість професійної підготовки та ефективне формування професійної мобільності, що може бути досягнуте лише шляхом модернізації змісту професійно-технічної освіти, запровадження нових педагогічних технологій, активної підтримки створення у професійно-технічних навчальних закладах органів учнівського самоврядування, некомерційних союзів та організацій.

У сучасних умовах будь-який навчальний заклад знаходиться в умовах жорсткої конкуренції. Сьогодні професійно-технічний навчальний заклад буде мати право на функціонування, якщо він $є$ джерелом технологічних та соціальних інновацій, готує компетентних та мобільних майбутніх кваліфікованих робітників, забезпечує соціокультурну та професійну адаптацію своїх випускників.

Отже, в умовах глобалізаційних процесів в Україні гостро постала проблема проектування змісту професійно-технічної освіти на основі модульнокомпететнісного підходу, який забезпечував би формування професійно мобільного кваліфікованого робітника, як необхідної умови виходу з економічної й соціальної кризи. Відсутність методологічних підгодів до проектування змісту професійнотехнічної освіти на основі модульно-компететнісного підходу гальмує процес модернізації професійно-технічної освіти в умовах швидкозмінних кількісних і якісних показників структур і форм зайнятості населення, постійно зростаючих вимог роботодавців до рівня кваліфікації випускників професійно-технічних навчальних закладів, активного впровадження у виробництво сучасних технологій, загальної інформатизації, значно актуалізується необхідність підвищення якості підготовки молоді до трудової діяльності в умовах динамічно змінного ринку праці.

Перспективи подальших досліджень пов'язуємо 3 розробленням заходів, спрямованих, зокрема на оновлення змісту професійно-технічної освіти, заснованого на компетенціях, його коригування з боку соціальних партнерів і потреб ринку праці.

\section{Література}

1. Горюнова Л.В. Профессиональная мобильность специалиста как проблема развивающегося образования в России: дис. ... доктора пед. наук: 13.00.08 / Горюнова Лилия Васильевна. - Ростов-на-Дону, 2006. - 337 с. 2. Дворецкая Ю. Ю. Психология профессиональной мобильности личности: дис. ... кандидата псих. наук: 19.00.01 / Дворецкая Юлия Юрьевна. - Краснодар, 2007. - 143 с. 3. Іванченко Є. А. Формування професійної мобільності майбутніх економістів у процесі навчання у вищих навчальних закладах: дис.. ... кандидата пед. наук:13.00.04 / Іванченко Свгенія Анатоліївна. - Одеса, 2005. - 181 с. 4. Игошев Б. М. Дополнительное профессиональное образование: новые ориентиры развития / Б. М. Игошев // Педагогика. - 2008. - № 2. - С. 44-48. 5. Кінах А. Стан і перспективи професійного розвитку трудового потенціалу України / Анатолій Кінах // Професійно-технічна освіта. - 2005. - № 3. - С. 2-7. 6. Кожемякіна Н. І. Соціально-педагогічні умови формування професійної мобільності майбутніх менеджерів-аграріїв : дис. ... кандидата пед. наук: 13.00.04 / Кожемякіна Наталія Іванівна. - Ізмаїл, 2006. - 167 с. 
7. Кремень В. Г. Освіта і наука в Україні - інноваційні аспекти. Стратегія. Розвиток. Результати/ Василь Григорович Кремень. - К.: Грамота, 2005. - 448 с. 8. Ничкало Н. Г. Трансформація професійно-технічної освіти України : [монографія] / Н. Г. Ничкало. - К. : Педагогічна думка, 2008. - 200 с. 9. Новиков А. М. Постиндустриальное образование / Александр Михайлович Новиков. - М. : Издательство «Эгвес», 2008. - 136 с. 10. Олейникова О. Основные векторы развития интеграционных процессов в области профессионального образования и обучения в ЕС [Электронный ресурс]/ Ольга Олейникова. - Режим доступа: http://www.eed.ru /opinions/ o-13-15.html. 11. Хакимова Н. Р. Профессиональное самоопределение личности и психологические условия его реализации в ситуации смены профессиональной деятельности : дис. ... кандидата психол. наук: 19.00.01 / Хакимова Н. Р. - Кемерово, 2005. - 179 с. 12. Ярошенко Г. Розвиток механізму взаємодії ринку праці і професійної освіти України / Г. Ярошенко, I. Заюков // Україна: аспекти праці. - 2007. - № 6. - С. 25-29.

$$
\text { УДК: } 378.147+538.3(075)+373.3
$$

\section{Тетяна Туркот, олександр Коновал}

\section{ІНДИВІДУАЛІЗАЦІЯ САМОСТІЙНОЇ РОБОТИ СТУДЕНТІВ-ФІЗИКІВ НА ЗАСАДАХ ВИМОГ ЗДОРОВ'ЯЗБЕРЕЖУВАЛЬНОГО НАВЧАННЯ}

Туркот Т. І., Коновал О. А. Індивідуалізація самостійної роботи студентів-фізиків на засадах вимог здоров'язбережувального навчання.

У статті обгрунтовано необхідність індивідуалізації самостійної роботи студентів-фізиків 3 позицій здоров'язбережувального навчання як умови забезпечення здоров’я молоді. Підкреслено, що реалізація принципу індивідуального підходу передбачає урахування особливостей стилів навчальної діяльності. Автори характеризують типологічні групи студентів, визначають методи їхньої самостійної навчальної діяльності під час вивчення фізики, які оптимально відповідають психологічним особливостям цих груп.

Ключові слова: здоров'язбережувальне навчання, інформаційний стрес, емоційний стрес, стиль навчальної діяльності, типологічні групи, психологічне «вигорання».

Туркот Т. И., Коновал О. А. Индивидуализация самостоятельной работы студентов-физиков на принципах требований здоровьесохраняющей учебы.

В статье обосновывается необходимость индивидуализации самостоятельной работы студентов-физиков с позиций здоровьесохраняющего обучения как условия обеспечения здоровья молодежи. Реализация принципа индивидуального подхода предполагает учет особенностей стиля учебной деятельности. Авторы характеризуют типологические группы студентов, определяют методы их самостоятельной учебной деятельности при изучении физики, которые оптимально соответствуют психологическим особенностям этих групп.

Ключевые слова: здоровьесохраняющее обучение, информационный стресс, эмоциональный стресс, стиль учебной деятельности, типологические группы, психологічне «вигорання».

Turkot T. I., Konoval O. A. Individualization of students-physicists' independent work on principles of requirements for health-consciosness training. 